\title{
The effects of temperature and oxygen availability on intracapsular development of Acanthina monodon (Gastropoda: Muricidae)
}

\author{
El efecto de la temperatura y la disponibilidad de oxígeno sobre el desarrollo intracapsular \\ de Acanthina monodon (Gastropoda: Muricidae)
}

MIRIAM FERNÁNDEZ ${ }^{1 *}$, PAULA PAPPALARDO \& KATHERINE JENO

\begin{abstract}
Estación Costera de Investigaciones Marinas of Las Cruces and Center for Advanced Studies in Ecology and Biodiversity, Departamento de Ecología, Facultad de Ciencias Biológicas, Pontificia Universidad Católica de Chile, Casilla 114-D, Santiago, 6513677, Chile

${ }^{1}$ International Associate Laboratory 'Dispersal and Adaptation in Marine Species' (Station Biologique de Roscoff and Center for Advanced Studies in Ecology and Biodiversity);

*e-mail for correspondence: mfernand@bio.puc.cl
\end{abstract}

\begin{abstract}
Freshwater and marine organisms show similar models of parental care and are faced with similar constraints to brood, which suggest that comparable environmental limits drive the evolution of parental care in aquatic systems. In fact, the low diffusion coefficient and solubility of oxygen in aquatic environments affect oxygen acquisition and therefore the capacity to aggregate embryos. The effect of other critical environmental variables, such as temperature, is less clear. We assessed the effects of temperature and oxygen availability on (1) the number of developed and undeveloped encapsulated embryos, (2) the proportion of embryos reaching advanced stages during intracapsular development (counting not only developed and undeveloped embryos but also abnormal embryos), (3) asynchrony in development (estimated only in capsules in which development occurred), and (4) final embryo size, as the first step toward identifying the main factors constraining parental care in the ocean. We used the gastropod Acanthina monodon as a model because it has an extended latitudinal range of distribution and exhibits feeding larvae during intracapsular development. The latter factor is relevant because previous studies have suggested that sibling cannibalism could be triggered by intracapsular competition for oxygen. Freshly laid egg capsules were collected and incubated until embryos hatched under different experimental temperatures (7, 11, 15 and $19{ }^{\circ} \mathrm{C}$ ) and oxygen conditions (hypoxia: 50-60\% air saturation; normoxia; and hyperoxia: 150-160\%). More embryos remained in early stages at the end of the experimental period under hypoxia and at the highest experimental temperature. The mean number of developed embryos was significantly lower under hypoxia conditions than under normoxia and hyperoxia, but was not influenced by temperature. However, temperature negatively affected embryo size of developed embryos and the level of asynchrony (number of different developmental stages per capsule). This suggests that even when a comparable number of embryos develops at high temperature, subsequent survival may be affected, since developed embryos attained smaller sizes. The negative effect of high temperature on embryo aggregation has also been reported for Brachyuran crabs, affecting female patterns of oxygen provision and brooding costs. This evidence suggests that aggregating embryos in the ocean, even under optimum oxygen conditions, may be negatively affected at high temperatures. Spatial patterns of distribution of brooding species in the ocean tend to agree with this prediction. Our analysis is particularly relevant given the current increase in temperature and the proportion of anoxic areas in the world's oceans.
\end{abstract}

Key words: brooding, intracapsular development, gastropods, oxygen, temperature.

\section{RESUMEN}

Los organismos marinos y dulceacuícolas muestran modelos similares de cuidado parental y están confrontados con similares restricciones para incubar, lo que sugiere que existen límites ambientales comparables guiando la evolución del cuidado parental en sistemas acuáticos. El bajo coeficiente de difusión y la baja solubilidad del oxígeno en ambientes acuáticos afecta la adquisición de oxígeno y por lo tanto la capacidad para agregar los embriones. El efecto de otras variables ambientales críticas, como la temperatura, es menos claro. Se evaluaron los efectos de la temperatura y la disponibilidad de oxígeno sobre (1) el número de embriones desarrollados y sin desarrollar, (2) la proporción de embriones que alcanza estados avanzados de desarrollo (contabilizando no solo embriones desarrollados y sin desarrollar sino también anormales), (3) 
la asincronía en el desarrollo (estimada solo cuando ocurrió desarrollo embrionario), y (4) el tamaño final, con el objetivo final de identificar las limitaciones que estos factores imponen sobre el cuidado parental en el mar. La especie modelo fue el gastrópodo Acanthina monodon. Cápsulas recientemente depositadas fueron colectadas e incubadas bajo diferentes condiciones experimentales de temperatura $\left(7,11,15 \mathrm{y} 19{ }^{\circ} \mathrm{C}\right)$ y oxígeno (hipoxia: 50-60 \% saturación de aire; normoxia; e hiperoxia: 150-160 \%). Más embriones permanecieron en fases tempranas del desarrollo al final del experimento en hipoxia y a $19{ }^{\circ} \mathrm{C}$. El número promedio de embriones desarrollados fue significativamente más bajo en hipoxia que bajo normoxia e hiperoxia, pero no fue influenciado por la temperatura. Sin embargo, la temperatura de incubación afectó otras variables de respuesta. Menores tamaños de los embriones y mayores niveles de asincronía al final del desarrollo fueron observados en las más altas temperaturas experimentales, lo que podría tener consecuencias negativas sobre la sobrevivencia posasentamiento. Las altas temperaturas también afectan el comportamiento y los costos asociados a la provisión de oxígeno a los embriones en braquiuros. Estas evidencias sugieren que agregar embriones en el océano, aun en condiciones óptimas de oxígeno, podría ser desfavorable a altas temperaturas. Los patrones espaciales de distribución de especies incubadoras tienden a apoyar esta predicción. Nuestro análisis también cobra relevancia en el escenario actual de aumento de la temperatura media de los océanos y de la proporción de zonas anóxicas.

Palabras clave: cuidado parental, desarrollo intracapsular, gastrópodos, oxígeno, temperatura.

\section{INTRODUCTION}

Freshwater and marine organisms exhibit similar modes of parental care and are faced with similar constraints in aggregating embryos. For instance, several taxa of aquatic organisms, from invertebrates to vertebrates, show similar types and shapes of embryo masses (Strathmann \& Strathmann 1989, Seymour \& Roberts 1991, Seymour et al. 1991, Crawford \& Balon 1996, Crump 1996, Fernández \& Brante 2003, Fernández et al. 2003, Green \& McCormick 2005). Moreover, these taxa are subjected to similar constraints on parental care at large body sizes (Strathmann \& Strathmann 1982, Crump 1996), a restriction that has enormous ecological, biogeographical and evolutionary consequences (Strathmann \& Strathmann 1982, Jablonski \& Lutz 1983). These similarities, exhibited by a wide range of taxa, suggest that comparable ecological conditions and environmental limits drive the evolution of parental care in aquatic systems. However, the main factors determining embryo development, affecting embryo aggregations, triggering sibling conflicts, and therefore shaping parental care in aquatic systems are poorly understood.

The physical characteristics of aquatic environments (low solubility of oxygen, low diffusion coefficient) affect oxygen acquisition in embryo aggregations (Strathmann \& Strathmann 1989, Fernández \& Brante 2003, Fernández et al. 2003, Green \& McCormick 2005). Over the last two decades several studies have shown that oxygen availability is a limiting factor in embryo aggregation in aquatic systems
(Strathmann \& Chaffee 1984, Strathmann \& Strathmann 1989, 1995, Cohen \& Strathmann 1996, Crump 1996, Fernández et al. 2003), directly affecting embryo developmental rates (Strathmann \& Strathmann 1995, Cohen \& Strathmann 1996, Cancino et al. 2003). Oxygen availability also seems to affect shell calcification in marine gastropods (MaedaMartinez 1985, Cancino et al. 2003), which may have enormous consequences on subsequent survival. The problem of oxygen acquisition imposed by aquatic systems can also help to explain the positive relationship between number of embryos and surface area of the capsule in marine gastropods (genus Conus; Perron \& Corpuz 1982). Moreover, oxygen availability also appears to determine the ratio between developed embryos and nurse eggs (Lardies \& Fernández 2002), suggesting that strong interactions (conflicts) may occur between siblings when an environmental condition such as oxygen availability becomes limiting. This body of evidence suggests that the strong oxygen limitation exhibited by embryo masses and capsules in aquatic systems may be an important evolutionary force, affecting the capacity to aggregate the embryos and therefore the spread of parental care in aquatic systems in general (Strathmann \& Strathmann 1982).

Embryo oxygen consumption determines oxygen availability in embryo aggregations, since diffusion of oxygen into the center of the aggregations usually is not sufficient to satisfy oxygen demands (Cohen \& Strathmann 1996, Baeza \& Fernández 2002, Fernández et al. 2003). As embryo oxygen demand increases 
throughout development, oxygen gradients between the center and the periphery of gelatinous embryo masses become stronger (Cohen \& Strathmann 1996, Brante et al. 2003). Actively brooding species, such as Brachyuran crabs, compensate for the higher oxygen demand of later embryonic stages by increasing the frequency of brooding behaviors that help provide oxygen to the embryos (e.g., abdominal flapping), thereby increasing the costs of brooding (Baeza \& Fernández 2002, Brante et al. 2003, Fernández et al. 2003). Temperature influences oxygen demand of the embryos (Wear 1974, Weathly 1981, Brante et al. 2003), which suggests that this environmental factor can also indirectly affect oxygen availability in embryo aggregations and thus embryo development, sibling interactions, brooding behaviors and costs, and consequently parental care. In fact, a strong relationship between temperature-dependent embryo oxygen demand and brooding behaviors associated to oxygen provision has already been reported in Brachyuran crabs (Brante et al. 2003). Moreover, the association between temperature and patterns of oxygen supply to the embryo mass increases the cost of brooding, suggesting that parental care in the ocean may be favored at low temperature (Brante et al. 2003). This prediction is supported by the high prevalence of brooding species in the deep ocean and at high latitudes, particularly in Antarctic waters (Thorson 1950, Gallardo \& Penchaszadeh 2001). The effect of temperature on other aspects of parental care, such as embryo developmental success (Cancino et al. 2003) and sibling conflicts in embryo aggregations has been less explored.

Encapsulated embryos offer a good model to investigate the effects of temperature and oxygen availability on embryonic development in aggregated masses, and the consequences on parental care, for two main reasons. First, species with encapsulated embryos can show wide ranges of latitudinal distribution (and therefore wide ranges of thermal conditions). Second, some species depend on siblings or nurse eggs as nutrition sources (e.g., Gallardo 1979, Gallardo \& Garrido 1987), which offers the opportunity to analyze the interactions between siblings triggered by environmental factors (Lardies \& Fernández 2002). Our goal was to assess the effects of temperature and oxygen availability on several indicators of embryonic development, to contribute to the understanding of the main factors constraining parental care in the ocean. We used the gastropod Acanthina monodon (Pallas 1774) as a model because it exhibits a feeding larva during intracapsular development and an extended latitudinal range of distribution. We analyzed four response variables: final number of developed and undeveloped encapsulated embryos, developmental success measured as the proportion of embryos reaching advanced stages during intracapsular development (counting not only developed and undeveloped embryos but also abnormal embryos), asynchrony in development (estimated only in capsules in which development occurred), and final embryo size. We also analyzed intracapsular oxygen availability to assess the effectiveness of the experiment. We discuss the effects of temperature and oxygen availability on embryo aggregations as well as the consequences on parental care and on the distribution of brooding species in the ocean.

\section{MATERIAL AND METHODS}

\section{Sample collections}

Acanthina monodon is a muricid gastropod that inhabits low intertidal rocky shores of central and southern Chile from 28 to $55^{\circ} \mathrm{S}$ (Gallardo 1979, Valdovinos et al. 1999). Capsules of Acanthina monodon exhibit fairly transparent walls which are yellowish shortly after deposition and turn grey as embryos develop (Gallardo 1979). Following this criteria, freshly laid egg capsules were collected from one site in central Chile (Consistorial, 33 ${ }^{\circ} 29^{\prime}$ S), where high densities of adult and capsules are found, and transported to the laboratory at the Estación Costera de Investigaciones Marinas (Las Cruces, central Chile) approximately $2 \mathrm{~km}$ away. Mean surface temperature in the study site is $13{ }^{\circ} \mathrm{C}$ during the reproductive months (April-September), ranging between 11,5 and $15,1{ }^{\circ} \mathrm{C}$. Females deposit capsules in aggregations, attached to rocky platforms, in areas of high wave exposure year round (Gallardo 1979). However, in our study area capsules are present only in autumn and winter. 


\section{Experimental design}

In order to assess the effects of temperature and oxygen availability on the response variables listed above, laboratory experiments were conducted. Capsules from different clutches were collected and randomly assigned to four experimental temperatures and three oxygen levels, until hatching. The experimental temperatures were $7,11,15$ and $19{ }^{\circ} \mathrm{C}$. This range of temperatures was selected because it includes the extreme temperatures within the latitudinal range of distribution of the species. Each temperature treatment was run at different times due to logistic constraints. Oxygen treatments were (1) Hypoxia, (2) Normoxia, and (3) Hyperoxia. Normoxia was established with a constant flow of air in the aquaria to maintain $100 \%$ air saturation. Hyperoxic conditions were created by bubbling $\mathrm{O}_{2}$ and $\mathrm{CO}_{2}$ to maintain 150-160\% air saturation. Hypoxic conditions were created by bubbling nitrogen and $\mathrm{CO}_{2}$ to maintain 50-60\% air saturation. We bubbled $\mathrm{CO}_{2}$ to minimize the changes in the $\mathrm{pH}$ which would have occurred if only nitrogen or oxygen had been used for the hypoxia and hyperoxia treatments, respectively. This level of air saturation was selected because oxygen levels below $50 \%$ air saturation have been shown to affect oxygen consumption of gastropods (Cancino et al. 2003). Temperature and oxygen conditions were monitored twice daily for all treatments. The effectiveness of the experimental oxygen conditions was assessed by monitoring extra and intracapsular oxygen availability (see Fig. 3).

Capsules were collected by detaching them from aggregations deposited by different females in the field. The experiment was started two days after the collection of capsules (initial time), allowing the capsules 48-h acclimation to the experimental conditions before the first measurements were made. Five 1-L containers were used for each combination of temperature and oxygen conditions. Ten capsules were randomly assigned to each container in order to have enough capsules to monitor embryo development throughout the experiment. However, only five replicates (one capsule from each container) were analyzed at the initial and final time for all the variables of interest. Therefore, the same number of replicates were used for the analysis of final number of embryos, proportion of developed embryos, asynchrony and embryo size. In each container, the capsules were allowed to float separately in order to avoid potential restriction in oxygen diffusion. At the initial time, one capsule from each treatment combination was randomly selected, and the following variables were measured: (a) intracapsular \% air saturation, (b) capsule size (maximum length and width), (c) number of embryos, and (d) stage of development of the embryos. Since temperature treatments were run at different times using different sets of capsules, a one way ANOVA was used to compare the initial number of embryos among temperatures. At the initial time, all embryos were at early stages of development (earlier than post-ingestion trochophore). No differences in the initial number of embryos per unit of capsule area among temperature treatments were detected $\left(\mathrm{F}_{3,17}=1.327, \mathrm{P}=0.298\right)$, which was a necessary condition to test for differences in embryo number at the end of the experiments. Thereafter, embryo development was monitored regularly until the advanced stages of veliger and pediveliger were reached in one of the oxygen treatments, at which time the experiment was ended. This was considered the final time, and then one capsule from each treatment combination was again randomly selected and the variables indicated above measured.

\section{Number of embryos}

The effects of experimental treatments on the number of embryos at the end of the experiment were evaluated. In some capsules, embryo development was severely retarded and early stage embryos were observed in some capsules while hatching was attained in the remaining contemporal treatments. Therefore, total embryo count at the end of the experiment did not necessarily reflect the effects of experimental treatments unless embryo stage was accounted for. Thus, the statistical analyses to assess the effects of experimental treatments on final number of embryos were conducted separately for developed and undeveloped embryos. Embryos were counted and the stage determined using a NIKON-SZ binocular microscope. Embryo stages were categorized following Gallardo (1979). The five categories 
used were: early embryos, post-ingestion trochophore, veliger, pediveliger, prejuveniles. We classified as developed embryos those reaching veliger to prejuvenile stages at the end of the experiment and as undeveloped embryos those attaining only the trochophore stage (Gallardo 1979). The number of embryos per capsule differed enormously between capsules containing undeveloped and developed embryos, because embryo number decreases 90 $\%$ throughout development in Acanthina monodon, as developing embryos depend on siblings as a source of food (e.g., Gallardo 1979, Gallardo \& Garrido 1987, Lardies \& Fernández 2002). Thus, two different approaches were used to estimate embryo number depending on developmental stage. In capsules containing undeveloped embryos at the end of the experiment, a subsample of the embryos was counted. Embryos were spread evenly on a dish divided in 113 equally sized squares and all the embryos were counted in 16 randomly selected squares. Based on this count, total egg number was estimated. All embryos were counted in capsules containing late stage embryos. When more than one developmental stage was found within a capsule, all embryos were counted and the stage determined. The size of the capsules ranged from 7.75 to 13.00 $\mathrm{mm}\left(\right.$ mean $\left._{ \pm} \mathrm{SD}=10.41 \mathrm{~mm}_{ \pm} 1.15\right)$. Since embryo number was positively correlated with capsule size (length: $\mathrm{P}<0.0001$, width: $\mathrm{P}<$ $0.0001)$, the number of embryos was standardized per unit of surface area of the capsule $\left(\mathrm{mm}^{2}\right)$ and used as a response variable. We selected capsule area because no correlation was found between number of embryos per unit of capsule area and capsule length $(\mathrm{P}=0.745)$ and because capsule area could be an indicator of oxygen exchange surface (Perron \& Corpuz 1982). Capsule area was estimated assuming the shape of a cylinder. Two-way ANOVAs were conducted to evaluate the effects of temperature and oxygen conditions on mean final number of undeveloped and developed stage embryos per unit of capsule area. Square-root transformation was used for undeveloped embryos to meet the assumptions of the model; arcsin for developed embryos. Tukey HSD tests were used for comparison among treatments.

In some capsules, a few developing but abnormal embryos were found. Since those embryos were neither classified as developed, nor as retarded, but could affect the number of embryos hatched, the proportion of developed embryos was estimated at the end of the experiment (number of developed embryos / total number of embryos) and was used as an indicator of developmental success. Total embryos resulted from the sum of abnormal, developed and retarded embryos. Two-way ANOVAs were used to assess the effects of temperature and oxygen condition ( $\%$ air saturation) on the mean proportion of embryos that developed. In the oxygen treatments in which embryo development occurred (excluding hypoxia, see below), a second twoway ANOVA was run to compare developmental success as well as asynchrony across treatments. Asynchrony was estimated as the sum of different embryonic stages within a capsule. Square-root transformation was used for the proportion of developed embryos to meet the assumptions of the ANOVA model. Tukey HSD tests were used for a-posteriori comparison.

\section{Embryo size}

In order to assess the effects of the experimental conditions on embryo size, the length of between 10 and 15 embryos per capsule were measured. The most advanced stages within a capsule were measured using an ocular micrometer using a Nikon-SZ binocular microscope. Then, the mean size of the most advanced embryos in each capsule was estimated. We focused on the most advanced stages in this case because otherwise the results were strongly biased by the number of undeveloped or slowly developed embryos. Other variables analyzed considered differences in embryo development among treatments. Mean embryo size was compared among temperatures and oxygen conditions using a two-way ANOVA. A Tukey HSD test was used for comparison among treatments.

\section{Intracapsular oxygen availability}

Intracapsular oxygen availability at the initial and final times was measured using a fiber optic sensor (Microx I, Presens) with a tip diameter ranging between 20 and $50 \mu \mathrm{m}$. The sensor was calibrated in a solution saturated 
with $\mathrm{Na}_{2} \mathrm{O}_{3} \mathrm{~S}$ (0\% air saturation) and in aerated water (100\% air saturation). The calibration and measurements were conducted at constant temperature, regulated by a thermostat. After calibration, oxygen availability ( $\%$ air saturation) was measured outside and then inside the capsules. The tip of the fiber optic was inserted in the center of the capsule and the capsule was then immersed in the experimental tank for the duration of the measurements. Each measurement was conducted for $15 \mathrm{~min}$, recording oxygen availability (\% air saturation) every $5 \mathrm{~s}$. The first and the last $2.5 \mathrm{~min}$ were discarded to avoid possible disturbances when the fiber optic was inserted or removed. Thus, $\%$ air saturation was calculated as the average of the remaining $10 \mathrm{~min}$ of measurements. Intracapsular \% air saturation was compared among temperatures and oxygen conditions using a two-way ANOVA, for each experimental time (initial and final). For initial oxygen conditions, cosine transformation was used. A-posteriori Tukey's tests (HSD) were conducted to determine differences among levels.

\section{RESULTS}

\section{Developmental time}

The trocophore was the most advanced stage observed at the end of the experiment in all hypoxia treatments. In contrast, in the other two oxygen treatments the veliger or pediveliger stages were attained. At normoxia, developmental time (days) increased substantially as temperature decreased beyond $11{ }^{\circ} \mathrm{C}$. Hatching occurred 112 days after the experiment started at $7{ }^{\circ} \mathrm{C}$, after 70 days at 11 ${ }^{\circ} \mathrm{C}, 50$ days at $15{ }^{\circ} \mathrm{C}$, and 47 days at $19{ }^{\circ} \mathrm{C}$. The capsules were freshly laid and the embryos were all at the same developmental stage when the experiment started.

\section{Number of embryos}

The significant interaction between the two main factors precluded us from testing the effects of temperature and oxygen conditions on mean final number of undeveloped embryos (Table 1, Fig. 1A). The interaction was due to the lack of change in the mean number of undeveloped embryos from low to high temperatures under hypoxia $(\mathrm{P}>0.05)$, which contrasted with the increase in the number of undeveloped embryos with temperature under normoxia and hyperoxia (Fig. 1A). More embryos remained in early stages at the end of the experimental period under hypoxia and at the highest experimental temperature under normoxia and hyperoxia $(\mathrm{P}<0.05)$. The remaining treatments formed a homogenous group lacking statistical distinction $(\mathrm{P}>0.05)$. The mean number of embryos attaining late stage (developed embryos) was significantly affected by oxygen conditions, but not by temperature (Table 1, Fig. 1B). The mean number of developed embryos was significantly lower under hypoxia conditions than in the other two oxygen treatments $(\mathrm{P}<0.05)$. No differences were found between normoxia and hyperoxia $(\mathrm{P}>0.05)$. The interaction term was not significant (Table 1).

Due to differences in the final number of undeveloped and developed embryos across treatments, and the presence of abnormal embryos, the mean proportion of developed embryos was compared. The interaction term was significant because again different patterns of developmental success occurred across temperatures in hypoxia than under the other two oxygen conditions (Table 2, Fig. 2A). The lowest proportion of developed embryos at the end of the experimental treatment was observed under hypoxia and at the highest temperature (19 ${ }^{\circ} \mathrm{C}$ both under normoxia and hyperoxia; $\mathrm{P}<$ 0.05 , Fig. 2A). The remaining treatments form a second homogenous group lacking statistical distinction $(\mathrm{P}>0.05)$. When the hypoxia treatment was excluded, since embryos never reached advanced developmental stages, a significant effect of temperature was detected $\left(\mathrm{F}_{3,29}=6.03, \mathrm{P}=0.0025\right)$. The mean proportion of advanced embryos at the end of development was lowest at $19{ }^{\circ} \mathrm{C}(\mathrm{P}<0.05)$. Asynchrony was significantly higher at the highest temperature $\left(\mathrm{F}_{3,29}=13.96, \mathrm{P}<0.0001\right.$, Fig. $\left.2 \mathrm{~A}\right)$. No differences were found among the remaining temperature treatments for asynchrony or developmental success $(\mathrm{P}>0.05)$ and between normoxia and hyperoxia (developmental success: $\mathrm{F}_{1,29}=0.99, \mathrm{P}=0.33$; asynchrony: $\mathrm{F}_{1,29}$ $=1.19, \mathrm{P}=0.28)$. The interaction terms were not significant (developmental success: $F_{3,29}=1.19$, $\mathrm{P}=0.33$; asynchrony: $\mathrm{F}_{3,29}=2.58, \mathrm{P}=0.07$ ). 


\section{TABLE 1}

Results of the two-way ANOVA conducted to compare mean number of embryos in capsules of Acanthina monodon at the end of the developmental period among oxygen conditions (hypoxia, normoxia, hyperoxia) and temperatures $\left(7,11,15\right.$ and $\left.19^{\circ} \mathrm{C}\right)$. The response variables were number of undeveloped and developed embryos per unit of capsule area. P-values $<0.05$ are indicated in bold

Resultados de los ANDEVA de dos vías realizados para comparar el número promedio de embriones en cápsulas de Acanthina monodon al final del período experimental bajo los diferentes niveles de los tratamientos de oxígeno (hiperoxia, normoxia e hipoxia) y temperatura $\left(7,11,15\right.$, y $\left.19^{\circ} \mathrm{C}\right)$. Las variables de respuesta fueron número de embriones desarrollados (tardíos) y sin desarrollar (tempranos) por unidad de área de cápsula. En negritas se indican los valores de significancia $<0,05$

\begin{tabular}{lcccccc}
\hline Source of variation & Degrees of freedom & F-value & P-value & Degrees of freedom & F-value & P-value \\
\hline & Embryos in early stage (undeveloped) & Embryos in late stage (developed) \\
Temperature & 3 & 7.03 & $\mathbf{0 . 0 0 0 6}$ & 3 & 1.73 & 0.17 \\
Oxygen & 2 & 74.85 & $\mathbf{< 0 . 0 0 1}$ & 2 & 64.11 & $<\mathbf{0 . 0 0 0 1}$ \\
Interaction & 6 & 3.02 & $\mathbf{0 . 0 1 5}$ & 6 & 2.09 & 0.072 \\
Error & 44 & & & 44 & \\
\hline
\end{tabular}

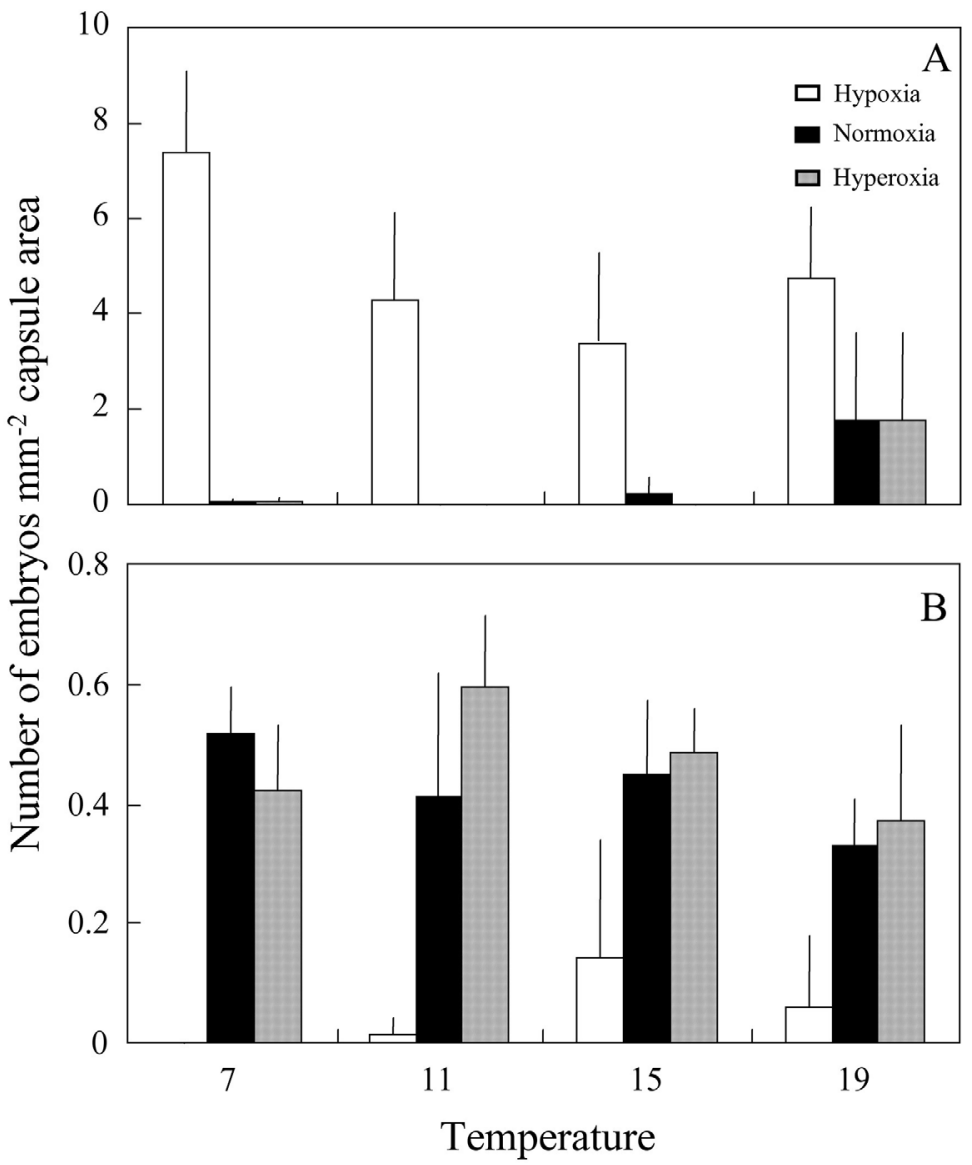

Fig. 1: Mean number of (A) undeveloped (early stages) and (B) developed (late stages) embryos at the end of the experimental period under different levels of oxygen (hyperoxia, normoxia and hypoxia) and temperature $\left(7,11,15\right.$, and $\left.19^{\circ} \mathrm{C}\right)$. Vertical bars indicate one standard deviation.

Número promedio de embriones (A) sin desarrollar (estadíos tempranos) y (B) desarrollados (estadíos tardíos) al final del período experimental bajo los diferentes tratamientos de oxígeno (hiperoxia, normoxia e hipoxia) y temperatura $(7,11,15$, y $\left.19^{\circ} \mathrm{C}\right)$. Las barras verticales indican una desviación estándar. 


\section{TABLE 2}

Results of the two-way ANOVA conducted to compare the mean proportion of developed embryos (developmental success) among oxygen (hypoxia, normoxia, hyperoxia) and temperature $(7,11,15$ and $19{ }^{\circ} \mathrm{C}$ ) treatments in capsules of Acanthina monodon. P-values $<0.05$ are indicated in bold

Resultados del ANDEVA de dos vías realizado para comparar el éxito del desarrollo embrionario, medido como la proporción de embriones desarrollados al final del experimento, entre los diferentes niveles de los tratamientos de oxígeno

(hiperoxia, normoxia e hipoxia) y temperatura $\left(7,11,15\right.$, y $\left.19{ }^{\circ} \mathrm{C}\right)$ en cápsulas de Acanthina monodon. En negritas se indican los valores de significancia $<0,05$

\begin{tabular}{lccc}
\hline Source of variation & Degrees of freedom & F-value & P-value \\
\hline Temperature & 3 & 609 & $\mathbf{0 . 0 0 1 5}$ \\
Oxygen & 2 & 42.54 & $<\mathbf{0 . 0 0 0 1}$ \\
Interaction & 6 & 2.42 & $\mathbf{0 . 0 4 1}$ \\
Error & 44 & & \\
\hline
\end{tabular}
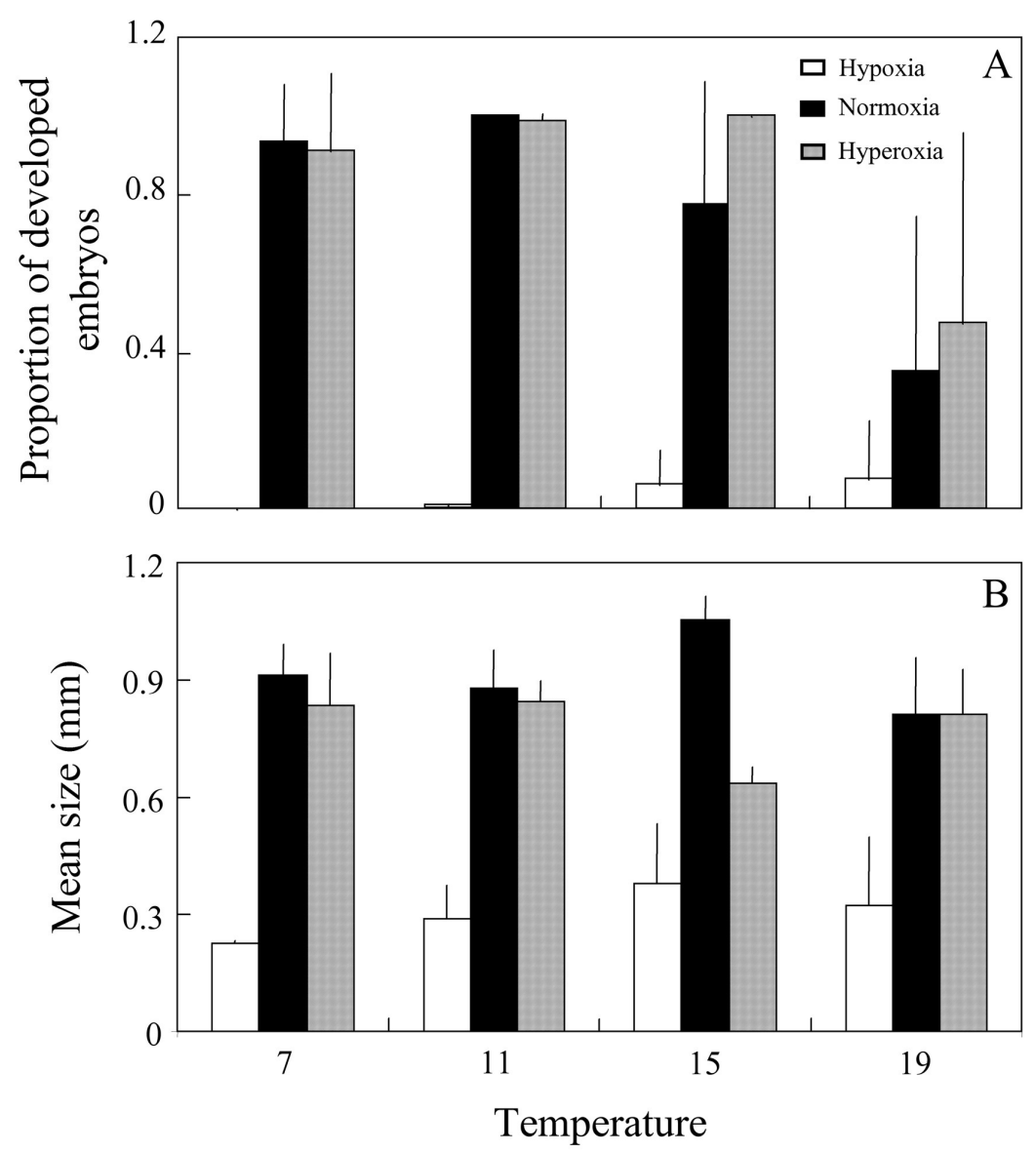

Fig. 2: Mean (A) proportion of developed embryos and (B) embryo size under different levels of oxygen (hyperoxia, normoxia and hypoxia) and temperature $\left(7,11,15\right.$, and $\left.19{ }^{\circ} \mathrm{C}\right)$. Vertical bars indicate one standard deviation.

Proporción promedio de embriones desarrollados (A) y tamaño promedio de los embriones (B) al final del período experimental bajo los diferentes tratamientos de oxígeno (hiperoxia, normoxia e hipoxia) y temperatura $\left(7,11,15\right.$, y $\left.19{ }^{\circ} \mathrm{C}\right)$. Las barras verticales indican una desviación estándar. 


\section{Embryo size}

A significant interaction between the main factors precluded us from testing the effects of temperature and oxygen condition on mean embryo size (Table 3). Hypoxia conditions affected embryo size of the most advanced stages within the capsule, as the smallest embryos were found at the end of the experimental period under hypoxia, regardless of temperature (Fig. 2B). Since development only reached the trocophora stage under hypoxia conditions, a second ANOVA including only the oxygen treatments in which more advanced embryo stages (between veliger and prejuvenile) were attained was conducted. The interaction term was also significant (Table 3) due to the lack of consistent patterns in embryo size between normoxia and hyperoxia across temperatures. It is worth pointing out that the statistically homogeneous group that exhibited the largest embryos included the lowest temperatures (hyperoxia incubated at the two lowest temperatures and the three lowest temperature of the normoxia treatment; Fig. 2B).

\section{Intracapsular oxygen conditions}

Extracapsular oxygen conditions reflected the experimental treatments (Fig. 3). A significant interaction in the ANOVA prevented us from testing for the effects of experimental oxygen condition and temperature on intracapsular \% air saturation at the beginning of the experiment (Table 4, Fig. 3). The interaction was due to the lack of difference between hyperoxia and normoxia at $7{ }^{\circ} \mathrm{C}$ in contrast with the higher $\%$ air saturation found under hyperoxia in the remaining temperatures (Fig. 3A). Three homogeneous group were identified, which reflected oxygen treatments (hyperoxia $>$ normoxia $>$ hypoxia; $\mathrm{P}<0.05$ ). At the end of the experiment, temperature treatments did not affect final intracapsular oxygen conditions, but oxygen treatments had a significant effect (Table 4, Fig. 3B). Capsules incubated under hyperoxia showed higher $\%$ air saturation than the other two treatments $(\mathrm{P}<0.05)$, which did not show significant differences (normoxia and hypoxia; $\mathrm{P}$ $>0.05$, Fig. 3).

\section{DISCUSSION}

This study provides further support for the importance of oxygen conditions on encapsulated embryo development in marine invertebrates (Strathmann \& Strathmann 1989, 1995, Cohen \& Strathmann 1996, Cancino et al. 2003), assessing also the effects of temperature on intracapsular development (Wear 1974, Weathly 1981, Brante et al. 2003). The experiments carried out showed a clear effect of hypoxia and high seawater temperature on

TABLE 3

Results of the two-way ANOVA conducted to test for differences in mean embryo size at the end of the experimental period in capsules of Acanthina monodon between oxygen (hypoxia, normoxia, hyperoxia) and temperature $\left(7,11,15\right.$ and $\left.19^{\circ} \mathrm{C}\right)$ treatments. The response variable was the mean size of the most advanced stages reached in each capsule. P-values $<0.05$ are indicated in bold

\footnotetext{
Resultados de los ANDEVAs de dos vías realizados para comparar el tamaño medio de los embriones al final del experimento en cápsulas de Acanthina monodon entre los diferentes niveles de los tratamientos de oxígeno (hiperoxia, normoxia e hipoxia) y temperatura $\left(7,11,15\right.$, y $\left.19^{\circ} \mathrm{C}\right)$. La variable de respuesta fue el tamaño medio de los estadíos más avanzados por cápsula. En negritas se indican los valores de significancia $<0,05$
}

\begin{tabular}{|c|c|c|c|c|c|c|}
\hline Source of variation & Degrees of freedom & F-value & P-value & Degrees of freedom & F-value & P-value \\
\hline & \multicolumn{3}{|c|}{ All treatments } & \multicolumn{3}{|c|}{ Excluding hypoxia treatments } \\
\hline Temperature & 3 & 0.52 & 0.67 & 3 & 0.98 & 0.4 \\
\hline Oxygen & 2 & 172.03 & $<0.0001$ & 1 & 19.64 & 0.0001 \\
\hline Interaction & 6 & 4.95 & 0.0006 & 3 & 9.46 & 0.0001 \\
\hline Error & 44 & & & 30 & & \\
\hline
\end{tabular}




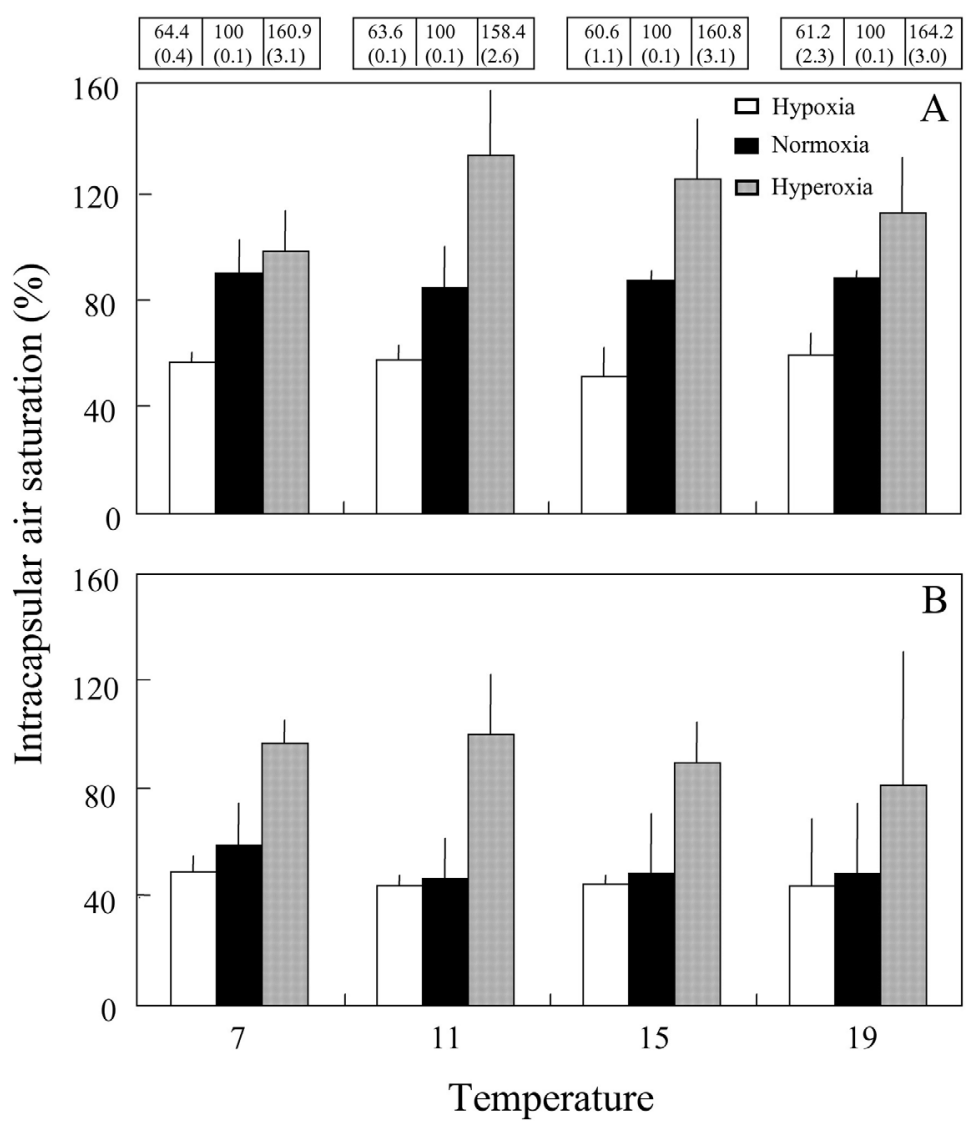

Fig. 3: Mean intracapsular oxygen condition at (A) initial and (B) final experimental times under different levels of oxygen (hyperoxia, normoxia and hypoxia) and temperature $(7,11,15$, and 19 ${ }^{\circ} \mathrm{C}$ ). The numbers above indicate the average extracapsular oxygen conditions (and standard deviation, between parentheses) in the hypoxia, normoxia and hyperoxia treatment throughout the experiment for each temperature. Vertical bars indicate one standard deviation.

Condición de oxígeno intracapsular en los tiempos (A) inicial y (B) final bajo diferentes condiciones de oxígeno (hiperoxia, normoxia e hipoxia) y temperatura $\left(7,11,15\right.$, y $\left.19^{\circ} \mathrm{C}\right)$. Los números mostrados arriba del gráfico superior indican la condición promedio de oxígeno extracapsular (y entre paréntesis la desviación estándar) bajo hipoxia, normoxia e hiperoxia. Las barras verticales indican una desviación estándar.

\section{TABLE 4}

Results of the two-way ANOVA conducted to compare intracapsular oxygen conditions (\% air saturation) under oxygen (hypoxia, normoxia, hyperoxia) and temperature $\left(7,11,15\right.$ and $\left.19{ }^{\circ} \mathrm{C}\right)$ treatments in capsules of Acanthina monodon, at the initial and the final experimental times. Pvalues $<0.05$ are indicated in bold

Resultados de los ANDEVAs de dos vías realizados para comparar las condiciones de oxígeno intracapsular (\% de saturación de oxígeno) bajo los diferentes tratamientos de oxígeno (hiperoxia, normoxia e hipoxia) y temperatura $(7,11$, 15 , y $19{ }^{\circ} \mathrm{C}$ ) en cápsulas de Acanthina monodon, en los tiempos experimentales inicial y final. En negritas se indican los valores de significancia $<0,05$

\begin{tabular}{|c|c|c|c|c|c|c|}
\hline Source of variation & Degrees of freedom & F-value & P-value & Degrees of freedom & F-value & P-value \\
\hline & \multicolumn{3}{|c|}{ Initial experimental time } & \multicolumn{3}{|c|}{ Final experimental time } \\
\hline Temperature & 3 & 0.76 & $<0.0001$ & 3 & 0.64 & 0.59 \\
\hline Oxygen & 2 & 120.27 & 0.52 & 2 & 28.26 & $<0.0001$ \\
\hline Interaction & 6 & 2.30 & 0.04 & 6 & 0.24 & 0.96 \\
\hline Error & 44 & & & 44 & & \\
\hline
\end{tabular}


embryo developmental success, size, and asynchrony in development. Both environmental variables exhibit strong spatial (Roy et al. 1998) and temporal (Smith et al. 1999, Gille 2002, Helly \& Levin 2004) variations in the ocean.

Embryo development was strongly affected by our experimental oxygen conditions, which is in line with other results suggesting the crucial effect of oxygen availability on embryo development (Booth 1995, Strathmann \& Strathmann 1989, Cohen \& Strathmann 1996, Lee \& Strathmann 1998, Woods 1999, Lardies \& Fernández 2002, Fernández et al. 2003), particularly during early development (Cancino et al. 2003). Our results show that under permanent low oxygen conditions (50-60\% extracapsular air saturation) development was strongly hindered; hatching was not achieved and a large number of embryos remained in early stage at the end of the experiment. In our study, developmental success reached only 0.02 $\%$ under hypoxia in comparison with the $79 \%$ of developed embryos found under normoxia. Since intracapsular oxygen conditions during late development did not differ between hypoxia and normoxia, the significant differences in intracapsular oxygen conditions among oxygen treatments during early development seemed to have determined embryo development in our study. After altering oxygen conditions between hypoxia and normoxia throughout development, Cancino et al. (2003) showed similar effects of hypoxia and also concluded that embryo sensitivity to low oxygen conditions is stronger during early development than in late development in another gastropod species. We suspect that hypoxic conditions are not rare in our study area, even in the intertidal zone, as adults and capsules can be exposed to extended periods (several weeks) of burial in sand.

The initial intracapsular \% air saturation clearly mimicked the experimental oxygen conditions, which is reflected in the increase in intracapsular oxygen availability from hypoxia to normoxia to hyperoxia. Those differences tended to disappear as embryos developed, showing the impact of embryo oxygen consumption on intracapsular oxygen availability, especially in treatments in which embryo development was successful (normoxia and hyperoxia). Although only the trocophora stage was reached in the hypoxia treatment, oxygen consumption seems to have occurred throughout the experimental period since intracapsular oxygen availability averaged 46 $\%$ air saturation at the end of the experiment while mean extracapsular \% air saturation was $62 \%$. This suggests that (1) oxygen consumption still occurred under the low oxygen conditions of the hypoxia treatment at the end of the experiment, although oxygen consumption was comparatively low, and (2) embryos may arrest development but do not necessarily die even after extended periods of hypoxia (Strathmann \& Strathmannm 1989, 1995). The $25 \%$ decrease between extra and intracapsular \% air saturation in the hypoxia treatment contrasts with the 49 and $42 \%$ air saturation differences between intracapsular and extracapsular oxygen availability in the normoxia and hyperoxia treatments. This implies that embryo oxygen consumption (1) was higher under normoxia and hyperoxia than in hypoxia, and (2) affected intracapsular oxygen conditions (Fig. 3). The effect of embryo oxygen consumption was more evident under normoxia (Fig. 3). The lack of effect of temperature on intracapsular oxygen conditions driven by temperature-dependent oxygen consumption of the embryos remains unexplained.

Although our results in general coincide with evidence in the literature, showing the effect of hypoxia on embryo development, the lack of differences in the number of developed embryos at the end of the experimental period between normoxia and hyperoxia contrasts with previous findings showing a clear effect of hyperoxia on the final number of developed embryos (Lardies \& Fernández 2002). When the response variable used by Lardies \& Fernández (2002) is compared with our results, the differences are notorious. We found that the mean number of developed embryos per mm of capsule was $5 \%$ higher (although no significant) in hyperoxia than in normoxia, in contrast with the $32 \%$ significant increase in the number of developed embryos under hyperoxia reported by Lardies \& Fernández (2002). Our study clearly shows that hyperoxia does not positively affect the mean number of developed embryos, regardless of temperature. Therefore, the conclusion that embryo development is determined by intracapsular oxygen conditions rather than by the 
assignation of nurse egg by the mother needs to be reconsidered (Lardies \& Fernández 2002). It is also interesting that slightly higher extracapsular oxygen conditions than our hypoxia treatment (75\% air saturation) did not affect developmental success of Acanthina monodon embryos when compared to normoxic conditions (Lardies \& Fernández 2002).

Although in general the effects of temperature were less clear than the effects of hypoxia, some variables were affected at the highest experimental temperature. The lowest developmental success was observed at $19{ }^{\circ} \mathrm{C}$, mostly driven by the higher number of undeveloped embryos found at the end of the experimental period. Developmental success was not affected by the number of abnormal embryos as similar patterns in the number of developed embryos and proportion of developed embryos were found across treatments. The mean number of developed embryos was not affected by temperature; however, the level of asynchrony and the mean size of the embryos were negatively affected at high temperatures. This suggests that even when a comparable number of embryos may develop at high temperature, their subsequent survival may be affected since developed embryos attained smaller sizes (see also Strathmann \& Strathmann 1995), which could affect rates of predation after hatching. The small size of the embryos may be associated with the lower consumption of nurse eggs (or siblings) since an important fraction of the undeveloped embryos remained at the end of the experiment (Fig. 2A). The negative effect of temperature on embryo aggregation has also been reported for Brachyuran crabs, affecting female patterns of oxygen provision and brooding costs (Brante et al. 2003). Moreover, a trade-off between investment in eggs and brooding at different temperatures (latitudes) has been documented (Brante et al. 2003). Our study, showing the effect of temperature on embryo development in aggregated masses, and previous studies on Brachyuran crabs suggest that aggregating embryos in the ocean, even under optimum oxygen conditions, may be negatively affected at high temperatures. It is remarkable that the frequency of brooding species seems to be higher in areas exhibiting low temperatures (Thorson 1950). Clear spatial patterns of distribution of brooding species have also been found among amphibians, supporting the generality of our analysis of causal factors affecting embryo aggregations and brooding in aquatic systems. This type of analysis becomes relevant considering the current increase in both the proportion of anoxic areas (Helly \& Levin 2004) and temperature in the world oceans (Smith et al. 1999, Gille 2002)

\section{ACKNOWLEDGMENTS}

We are grateful to A. Brante, R. Calderon, C. Gonzalez, M. Cifuentes, C. Inostroza, R. Soto and F. Veliz for their help collecting capsules and in the laboratory. We also thank R. Finke, J. Holl, S. Kimberlin, and two anonymous reviewers for their suggestions on the manuscript. This study was fully funded by FONDECYT 1020860 (to MF). We also acknowledge the Humboldt Foundation. MF acknowledges the FONDAP-Fondecyt grant 1501-0001 to the Center for Advanced Studies in Ecology \& Biodiversity and the Pew Fellows Program in Marine Conservation.

\section{LITERATURE CITED}

BAEZA JA \& M FERNÁNDEZ (2002) Active brood care in Cancer setosus (Crustacea: Decapoda): the relationship between female behavior, embryo oxygen consumption and the cost of brooding. Functional Ecology 16: 241-251.

BOOTH D (1995) Oxygen availability and embryonic development in sand snail egg masses. The Journal of Experimental Biology 198: 241-247.

BRANTE A, M FERNÁNDEZ, L ECKERLE, F MARK, HO PORTNER \& W ARNTZ (2003) Reproductive investment in the crab Cancer setosus along a latitudinal cline: egg production, embryo losses and embryo ventilation. Marine Ecology Progress Series 251: 221-232

CANCINO JM, JA GALLARDO \& FA TORRES (2003) Combined effects of dissolved oxygen concentration and water temperature on embryonic development and larval shell secretion in the marine snail Chorus giganteus (Gastropoda: Muricidae). Marine Biology 142: 133-139.

COHEN CS \& R STRATHMANN (1995) Embryos at the edge of tolerance: effects of environment and structure of egg masses on supply of oxygen to embryos. Biological Bulletin 190: 8-15.

CRAWFORD S \& E BALON (1996) Cause and effect of parental care in fishes. In: Slater P, J Rosenblatt, Ch Snowdon \& M Milinski (eds) Advances in the study of behavior 25: 53-107. Academic Press, New York, New York, USA.

CRUMP M (1996) Parental care among the amphibians. 
In: Slater P, J Rosenblatt, Ch Snowdon \& M Milinski (eds) Advances in the study of behavior 25: 109-144. Academic Press, New York, New York, USA.

FERNÁNDEZ M \& A BRANTE (2003) Brood care in Brachyuran crabs: the effect of oxygen provision on reproductive costs. Revista Chilena de Historia Natural 76: 157-168.

FERNÁNDEZ M, N RUIZ-TAGLE, S CIFUENTES, HO PORTNER \& W ARNTZ (2003) Oxygen-dependent asynchrony of embryonic development in embryo masses of brachyuran crabs. Marine Biology 142: $559-565$

GALLARDO CS (1979) Developmental pattern and adaptations for reproduction in Nucella crassilabrum and other muricacean gastropods. Biological Bulletin 157: 453-463.

GALLARDO CS \& O GARRIDO (1987) Nutritive egg formation in the marine snails Crepidula dilatata and Nucella crassilabrum. International Journal of Invertebrate Reproduction and Development 11: 239-254.

GALLARDO CS \& PE PENCHASZADEH (2001) Hatching mode and latitude in marine gastropods: revisiting Thorson's paradigm in the southern hemisphere. Marine Biology 138: 547-552.

GILLE ST (2002) Warming of southern ocean since the 1950's. Science 295: 1275-1277.

GREEN BS \& MI MCCORMICK (2005). Maternal and paternal effects determine size, growth and performance in larvae of a tropical reef fish. Marine Ecology Progress Series 289: 263-272.

HELLY JJ \& LA LEVIN (2004) Global distribution of naturally occurring marine hypoxia on continental margins. Deep-Sea Research I 51: 1159-1168.

HORMAZÁBAL \& P SEHLSTEDT (2000) Warming and circulation change in the eastern south Pacific ocean. Geophysical Research Letters 27: 12471250

JABLONSKI D \& RL LUTZ. (1983) Larval ecology of marine benthic invertebrates: paleobiological implications. Biological Reviews 58: 21-89.

LARDIES MA \& M FERNÁNDEZ (2002) Effect of oxygen availability in determining clutch size in Acanthina monodon. Marine Ecology Progress Series 239: 139-146.

LEE CE \& R STRATHMANN (1998) Scaling of gelatinous clutches: effects of siblings competition for oxygen on clutch size and parental investment per offspring. American Naturalist 151: 293-310.

MAEDA-MARTÍNEZ AN (1985) Studies on the physiology of shell formation in the molluscan larvae, with special reference to Crepidula fornicata. Ph.D. thesis, Department of Oceanography, University of Southampton, Southampton, United Kingdom. 189 pp.

PERRON FE \& GC CORPUZ (1982) Costs of parental care in the gastropod Conus pennaceus: age specific changes and physical constraints. Oecologia 55: 319-324.

Associate Editor: Jorge Navarro

Received December 10, 2005; accepted March 20, 2006
ROY K, D JABLONSKI, J VALENTINE \& G ROSENBERG (1998) Marine latitudinal diversity gradients: test of causal hypothesis. Proceedings of the National Academy of Sciences USA 95: 36993702.

SEYMOUR RS \& DJ ROBERTS (1991) Embryonic respiration and oxygen distribution in foamy and nonfoamy egg masses of the frog Limnodynastes tasmaniensis. Physiological Zoology 64: 13221340.

SEYMOUR RS, F GEISER \& DF BRADFORD (1991) Gas conductance of the jelly capsule of terrestrial frog eggs correlates with embryonic stage, not metabolic demand or ambient $\mathrm{PO}_{2}$. Physiological Zoology 68: 206-222.

SMITH RC, D AINLEY, K BAKER, E DOMACK, S EMSLIE, W FRASER, J KENNETT, A LEVENTER, E MOSLEY-THOMPSON, S STAMMERJOHN \& M VERNET (1999) Marine ecosystem sensitivity to climate change. BioScience 49: 393-404.

STRATHMANN R \& M STRATHMANN (1982) The relationship between adult size and brooding in marine invertebrates. American Naturalist 119: 91101.

STRATHMANN R \& C CHAFEE (1984) Constraints on egg masses 2. Effect of spacing, size, and number of eggs on ventilation of masses of embryos in jelly, adherent groups, or thin-walled capsules. Journal of Experimental Marine Biology and Ecology 84: 85-93.

STRATHMANN R \& M STRATHMANN (1989) Evolutionary opportunities and constraints demonstrated by artificial gelatinous egg masses, reproduction, genetics and distribution of marine organisms. 23 $3^{\text {rd }}$ European Marine Biology Symposium, Olsen \& Olsen. , Editorial, Ciudad, País, pp: 201-209.

STRATHMANN R \& M STRATHMANN (1995) Oxygen supply and limits on aggregation of embryos. Journal of Marine Biology Association (United Kingdom) 75: 413-428.

THORSON G (1950) Reproductive and larval ecology of marine bottom invertebrates. Biological Reviews 25: $1-45$.

VALDOVINOS CR (1999) Biodiversidad de moluscos chilenos: base de datos taxonómica y distribucional. Gayana Zoología (Chile) 63: 59-112.

WEAR R (1974) Incubation in British decapods crustacean and the effects of temperature on the rate of success of embryonic development. Journal of Marine Biology Association (United Kingdom) 54: 745 762.

WHEATLY MG (1981) The provision of oxygen to developing eggs by female shore crabs (Carcinus maenas). Journal of Marine Biology Association (United Kingdom) 61: 117-128.

WOODS HA (1999) Egg-mass size and cell size: Effects of temperature on oxygen distribution. American Zoologist 39: 244-252. 